\title{
PRAKTEK BANGUN RUMAH TINGGAL DENGAN SISTEM ARISAN DALAM TINJAUAN HUKUM ISLAM
}

\author{
Safaruddin, Saifuudin, \\ Prodi Hukum Ekonomi Syariah, Fakultas Agama Islam, Universitas Al Asyariah Mandar
}

\begin{abstract}
Abstrak
Tujuan penelitian ini adalah : 1) Untuk mengetahui bagaimana praktek bangun rumah tinggal dengan sistem arisan dalam tinjauan hukum Islam di Kampung Kamande Desa Pollewani Kecamatan Tutar Kabupaten Polewali Mandar. 2) Untuk mengetahui bagaimana tinjauan hukum Islam terhadap praktek bangun rumah tinggal dengan sistem arisan di Kampung Kamande. Jenis penelitian ini menggunakan to deskribe kualitatif. Untuk itu, penelitian ini menggunakan grant tour qoustion dalam bentuk observasi, wawncara dan dokumentasi terhadap pelaksana, proses dan pengamat untuk mengumpulkan data yang sifatnya kualitatif. Data yang terkumpul selanjutnya dirangkum dan dihubungkan antara kategori dan mewujudkan dalam bentuk kesimpulan. Hasil penelitian menunjukkan bahwa arisan bangun rumah dijalankan oleh 20 orang dengan kesepakatan setiap anggota wajib membayar Rp.1,000,000,- tenaga selama 10 hari kerja, dan konsumsi. Selanjutnya dipinjamkan kepada penerima undian dengan cara mengundi melalui pertemuan yang wajib dihadiri oleh seluruh anggota. Arisan ini adalah praktek dari akad Al-qardh. Nama yang mendapat undian lebih awal sebagai pihak yang berhutang, dan nama yang mendapat undian lebih akhir sebagai pihak yang berpiutang. Praktek bangun rumah tinggal dengan sistem arisan hukumnya adalah mubah yang telah sesuai dengan syariat islam, dikonfirmasi dengan dampak maslahat dan tidak ditemukannya penyimpangan dan eksploitasi terhadap sesama. Implikasi dari penelitian ini adalah, 1) Praktek bangun rumah tinggal dengan sistem arisan merupakan organisasi swadaya masyarakat yang sangat berperan dalam pembangunan. 2) Arisan merupakan bagian dari muamalah yang hukumnya boleh sejauh prakteknya sejalan dengan prinsip-prinsip dasar muamalah.
\end{abstract}

Kata Kunci : Arisan bangun rumah kampung kamande.

Abstract

The purpose of this research are: 1) To find out how the practice of building a house with a social gathering system in the review of Islamic law in Kampung Kamande, Pollewani Village, Tutar District, Polewali Mandar Regency. 2) To find out how to review Islamic law on the practice of building a house with a social gathering system in Kamande Village. This type of research uses qualitative deskribe. For this reason, this study uses a grant tour qoustion in the form of observations, interviews and documentation of implementers, processes and observers to collect qualitative data. The collected data is then summarized and linked between categories and realized in the form of conclusions. The results of the study showed that arisan to build a house was run by 20 people with the agreement that each member was required to pay Rp. 1,000,000, labor for 10 working days, and consumption. Subsequently lent to the lottery recipients by drawing through a meeting that must be attended by all members. This arisan is the practice of the Al-qardh contract. The name that gets the lottery earlier as the party owed, and the name that gets the lottery later as the party that owes. The practice of building a house with a legal social gathering system is a mubah that is in accordance with Islamic law, confirmed with the impact of benefits and the discovery of irregularities and exploitation of others. The implications of this research are, 1) The practice of building a house with a social gathering system is a non-governmental organization that is very instrumental in development. 2) Arisan is a part of muamalah whose law is allowed as long as the practice is in line with the basic principles of muamalah.

\section{PENDAhuluan}

A. Latar Belakang

Manusia adalah makhluk hidup yang mempunyai kebutuhan ber-aneka ragam dan sangat kompleks. Kebutuhan merupakan segala sesuatu yang dapat menunjang hidup manusia. Kebutuhan akan selalu dihadapkan pada kelansungan hidup dalam mempertahankan eksistensinya sebagai khalifah di muka bumi. Kebutuhan pada dasarnya terbagi atas dua yaitu kebutuhan yang bersifat materi dan non materi. Kebutuhan materi seperti kebutuhan untuk makan dan minum, pakaian, maupun tempat tinggal. Sementara kebutuhan non materi adalah kebutuhan yang bersifat jasmani dan rohani seperti pengetahuan, motivasi, kesehatan dan hubungan biologis. 
Hidup manusia akan selalu dirundung berbagai jenis kebutuhan. Teori konfensional mengatakan bahwa kebutuhan yang tidak terbatas dengan sumber daya yang sangat terbatas, tentunya akan menjadi pekerjaan rumah bagi semua pihak untuk kesejahteraan masyarakat. Berbagai jenis masalah telah dihadapi manusia dalam pemenuhan kebutuhan hidupnya. Satu masalah besar adalah adanya kesenjangan yang tajam antara kebutuhan dan sumber daya yang tersedia.

Kegiatan muamalah yang berkembang ditengah masyarakat sangat beragam, diantaranya yang sering kita saksikan adalah praktek muamalah dengan sistem arisan. Secara umum arisan atau tabungan bersama (company saving) merupakan perkumpulan uang yang diundi secara berkala dalam kurung waktu tertentu. Dalam perkumpulan tersebut setiap anggota diwajibkan menyetor sejumlah uang sesuai yang telah disepkati. Kemudian uang yang terkumpul tersebut diberikan kepada yang mendapatkan undian. Undian dilakukan dalam sebuah pertemuan yang wajib dihadiri oleh setiap peserta dalam kurung waktu tertentu. Itu terus dilakukan secara berulang hingga seluruh peserta mendapatkan undian.

Arisan umumnya hanya identik bagi ibu-ibu rumah tangga dengan obyek arisan yang beragam seperti arisan uang, barang dan jasa. Namun seiring perkembangannya, arisan mendapat perhatian dari berbagai kalangan termasuk juga kaum pria (bapak-bapak), seperti yang terjadi di Kamande Desa Pollewani Kecamatan Tutar Kabupaten Polewali Mandar. Praktek arisan bangun rumah di Kampung Kamande ini, para pesertanya merupakan ibu-ibu dan kepala rumah tangga yang berperan sebagai kreditur sekaligus debitur arisan. Jenis arisannya pun tergolong komplit dengan masih dalam akad yang sama namun terdiri dari berbagai jenis produk yang ditawarkan, seperti arisan uang, bahan bangunan, pekerjaan bangunan, hingga arisan konsumsinya seperti beras, minyak, dan ikan.

Arisan bangun rumah terletak di Kampung Kamande Desa Pollewani tersebut bermula hanya dengan arisan yang terdiri dari material bangunan saja seperti semen, batu merah, besi dan lain-lain. Namun pada tahun 2017 arisan ini berkembang seiring dengan kebutuhan para anggota, sehingga dibentuk pula arisan tenaga kerja yang menjadi faktor utama diminatinya arisa ini. sebab tujuan mendasar dari arisan ini yaitu untuk memudahkan warga saat mendirikan rumah tanpa harus mengeluarkan biaya khusus untuk arsitek bangunan.

Hipotesis dari pengamatan yang penulis amati, bahwa arisan ini meskipun punya peran yang besar dalam membangun desa, khususnya ketersediaan rumah-rumah warga. Namun ada juga hal-hal mendasar yang mejadi polemik dari arisan ini, sehingga penulis tertarik untuk meneliti lebih lanjut dan menuangkan dalam bentuk laporan skripsi sebagai salah satu syarat dalam menyelesaikan study sarjana hukum pada Fakultas Agama Islam di Universitas Al Asyariah Mandar.

Arisan ini seperti pada umumnya yaitu dilakukan oleh sekelompok orang dengan kesepakatan bersama dalam mengumpulkan sejumlah uang atau barang kemudian diberikan dengan cara mengundi dan dilakukan secara berulang sampai seluruh anggota mendapatkan undian. Arisan bangun rumah di Kamande Desa Pullewani ini diikuti sejumlah 70 orang yang terdiri dari tiga kelompok, setiap anggota menyetor uang senilai Rp.1,000,000 kepada ketua kelompok dan diundi dalam pertemuan sederhana untuk menentukan siapa yang akan menggunakan uang tersebut dalam membangun rumah tinggal. Dalam hal ini, yang menjadi permasalahan adalah harga yang sifatnya fluktuatif akan sangat berpengaruh dalam berjalannya sistem arisan ini.

Undian pertama yang dilakukan pada bulan januari tahun 2017 dengan nominal uang yang terkumpul Rp.25,000,000/kelompok, dengan harga semen Rp.48,0000/sak, akan memmperoleh 520 sak semen dengan harga komulatif Rp.24.960.000. namun undian ketiga pada bulan januari tahun 2018 dimana harga semen naik dari Rp.48,000 menjadi Rp.50.000/sak. Sehingga nominal uang yang terkumpul sebesar Rp.25,000,000/kelompok, hanya akan memperoleh 500 sak semen. Sehingga penerima undian pertama tahun 2017 memperoleh semen 520 sak (Rp.24,960,000) sementara penerima undian ketiga tahun 2018 hanya memperoleh 500 sak (Rp.25,000,000). Jika diamati, ada ketimpangan terhadap 
perolehan hak antara peserta undian pertama dengan undian ketiga dengan selisih 20 sak semen Rp. $40,000 .{ }^{1}$

Ketimpangan yang terjadi diatas, bisa saja lebih berdampak fatal lagi jika tidak dilakukan dengan pengawasan dan prinsip kehati-hatian terhadap penyimpangan syariat Islam. Oleh karena itu, tujuan utama dari penelitian ini adalah untuk mengetahui bagaimana tinjauan hukum Islam terhadap arisan bangun rumah tinggal di Kamande Desa Pollewani serta bagaimana prakteknya.

Berdasarkan uraian latar belakang masalah diatas, maka yang menjadi rumusan masalah penelitian ini adalah:

1. Bagaimana Praktek Bangun Rumah Tinggal dengan Sistem Arisan di Kampung Kamande Desa Pollewani Kecamatan Tutar Kabupaten Polewali Mandar.?

2. Bagaimana Tinjauan Hukum Islam Terhadap Praktek Bangun Rumah Tinggal dengan Sistem Arisan di Kampung Kamande Desa Pollewani Kecamatan Tutar Kabupaten Polewali Mandar.?

\section{TINJAUAN PUSTAKA}

\section{A. Arisan}

Arisan adalah sekelompok orang yang mengumpulkan uang atau barang secara teratur pada tiaptiap periode tertentu. Setelah uang terkumpul, salah satu dari anggota kelompok akan keluar sebagai pemenang. Penentuan pemenang biasanya dilakukan dengan jalan pengundian, perjanjian antara anggota arisan, dengan nomor urut anggota, atau berdasarkan prioritas kebutuhan anggota arisan.

Menurut kamus umum bahasa Indonesia, arisan adalah kegiatan mengumpulkan uang atau barang yang bernilai sama oleh beberapa orang kemudian diundi di antara mereka untuk menentukan siapa yg akan memperolehnya. Undian dilaksanakan dalam sebuah pertemuan secara berkala sampai semua anggota memperolehnya. ${ }^{2}$

Arisan yang terdapat dilingkungan masyarakat ada empat macam model arisan yaitu : arisan uang, arisan barang, arisan jasa/tenaga dan arisan spiritual. Untuk arisan spiritual disebutkan perkembangan baru tentang arisan dalam konunitas umat Islam khususnya, misalnya arisan yasinan dan arisan hewan qurban.

Arisan merupakan bentuk muamalah yang dilakukan oleh sekelompok orang yang bertujuan untuk mempermudah suatu pekerjaan dengan prinsip utama gotong royong. Sistem pemenuhan kebutuhan manusia terus berkembang seakan tidak ada titik jenuh, sehingga syariat menjadi penuntun bagi para pelaku muamalah agar tidak terjadi eksploitasi antara manusia

Menurut kamus besar Bahasa Indonesia, arisan adalah kegiatan mengumpulkan uang atau barang yang bernilai sama oleh beberapa orang kemudian di undi diantara mereka untuk menentukan siapa yang memperolehnya. Undian dilaksanakan dalam sebuah pertemuan secara berkala sampai semua anggota memperolehnya. Dengan defenisi di atas jelaslah bahwa arisan terdiri dari dua kegiatan pokok yaitu :

1. Pengumpulan uang atau barang dan sejenisnya yang bernilai sama.

2. Mengundi di antara peserta atau pengumpul untuk menentukan siapa yang akan memperoleh.

Undian bukanlah istilah asin dalam literatur Islam seperti yang dibahasakan dalam hadits yaitu Qur'ah. Hal itu pernah dilakukan oleh Nabi Muhammad Saw terhadap istri-istrinya saat hendak bepergian.

Sebagaimana Aisyah Radhiallahu 'anha menceritakan :

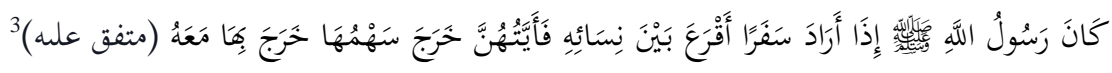

Artinya:

\footnotetext{
${ }^{1}$ Wawancara dengan Pak.Rusli selaku ketua Kelompok Arisan Kamande. 25 maret 2020;

${ }^{2}$ Wjs. Poerwadarminta, Kamus Umum Bahasa Indonesia, (Jakarta: Balai Pustaka, 2003) h. 59;

${ }^{3}$ https://sumsel.kemenag.go.Islam Kemenag Sumsel. Pdf (07 januari 2020);
} 
Apabila Rasulullah Saw hendak safar, beliau mengundi di antara istri-istrinya. Siapa yang namanya keluar, beliau berangkat bersama istrinya yang menang." (HR. Bukhari No. 2593, dan Muslim No. 7196)

Ketika Maryam masih kecil, untuk menetapkan siapa yang berhak memeliharanya, mereka mengadakan pengundian dan Nabi Zakarialah yang berhak memeliharanya. Sebagaimana firman Allah Swt. dalam Q.S. Ali-‘imran/3: 44.

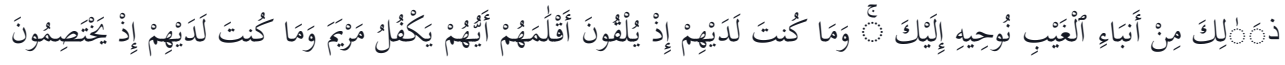

Terjemahnya:

Yang demikian itu adalah sebagian dari berita-berita ghaib yang kami wahyukan kepada kamu (Ya Muhammad); padahal kamu tidak hadir beserta mereka, ketika mereka melemparkan anak-anak panah mereka (untuk mengundi) siapa di antara mereka yang akan memelihara Maryam. dan kamu tidak hadir di sisi mereka ketika mereka bersengketa. ${ }^{4}$

Hukum arisan secara konsep adalah boleh (mubah). Hal ini didasarkan atas kesepakatan bersama, tidak mengandung unsur riba dan kedudukan semua orang setara dan memiliki hak yang sama. Secara mekanisme arisan juga mubah karena dalam proses pengundiannya bersifat secara adil dan tidak merugikan pihak tertentu (tidak ada yang menang atau kalah). Secara pelaksanaan apabila seseorang memenuhi janjinya sesuai dengan kesepakatan tersebut maka hukumnya mubah.

\section{B. Akad}

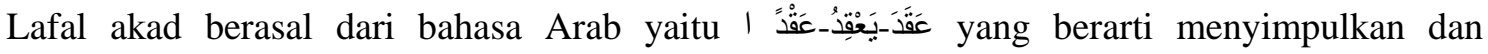
membuhulkan tali. ${ }^{5}$ Dalam ensiklopedi hukum islam, akad (al-'aqd = perikatan, perjanjian, dan pemufakatan (al-ittifaq)). Secara istilah fiqih, akad didefinisikan sebagai pertalian ijab (pernyataan melakukan ikatan) dan qabul (pernyataan penerima ikatan) sesuai dengan kehendak syariat yang berpengaruh pada objek perikatan. Yang dimaksud dengan "yang sesuai dengan kehendak syariat" adalah bahwa seluruh perikatan yang dilakukan oleh dua belah pihak atau lebih tidak boleh apabila tidak sejalan dengan kehendak syarak, misalnya kesepakatan dalam melakukan transaksi riba, menipu orang lain atau merampok kekayaan orang lain.

Mustafa Ahmad Az-Zarqa (tokoh fiqh Yordania asal Suriah) menyatakan dalam pandangan syarak, suatu akad merupakan ikatan secara hukum yang dilakukan oleh dua atau beberapa pihak yang sama-sama berkeinginan untuk mengikat diri. ${ }^{6}$

Kata 'aqad dalam istilah bahasa berarti ikatan dan tali pengikat. Jika dikatakan 'aqada al-habla maka itu mengabungkan antara dua ujung tali lalu mengikatnya, kemudian makna ini berpindah dari hal yang bersifat hissi (indra) kepada ikatan yang tidak tampak antara dua ucapan dari kedua belah pihak yang sedang berdialog. Dari sinilah kemudian makna akad diterjemahkan secara bahasa sebagai "menghubungkan antara dua perkataan, masuk juga didalamnya janji dan sumpah, karena sumpah menguatkan niat berjanji untuk melaksanakan isi sumpah atau meninggalkannya. Demikian juga halnya dengan janji sebagai perekat hubungan antara kedua belah pihak yang berjanji dan menguatkannya.

Dilihat dari segi tujuannya, akad terbagi dua yaitu:

\section{Akad Tabarru'}

Tabarru' merupakan akad yang bertujuan untuk saling tolong menolong dan murni semata-mata karena mengharap ridha dan pahala dari Allah Swt., dan sekali-kali tidak ada motif mencari keuntungan dan tujuan komersil. Akad yang termasuk dalam kategori ini adalah: Hibah, Wakaf, Wasiat, Kafalah, Hawalah, Rahn, Qard dan lain-lain.

\footnotetext{
${ }^{4}$ Mohamad Taufiq. Quran In Word: Q.S. Ali-‘imran/3: 44;

${ }^{5}$ Mahmud Yunus, Kamus Arab-Indonesia (Jakarta: PT. Hida karya agung) , h. 274;

${ }^{6}$ A. Rahman Ritonga, Ensiklopedi Hukum Islam, (Jakarta: Pt Ichtiar Baru Van Hoeve,2006). 6 Jil, Cet.
} Ke-1, h. 63; 


\section{Akad Tijari}

Akad tijari merupakan akad yang bertujuan mencari dan mendapatkan keuntungan saat rukun dan syarat telah terpenuhi. Akad yang termasuk dalam kategori ini adalah Musyarakah, Murabahah, Salam, Istisna, Ijarah muntahhiya bittamlik dan Mudharabah.

Dilihat dari keabsahannya, akad terbagi atas dua yaitu:

a) Akad Shahih, yaitu akad yang telah terpenuhi rukun dan syaratnya.

b) Akad Fasad (rusak), jika ada prinsip dan sifatnya yang tidak dibenarkan.

c) Akad Tidak Sah (Batal), apabilah ada salah satu dari rukun dan syarat tidak terpenuhi.

c. Al-qardh

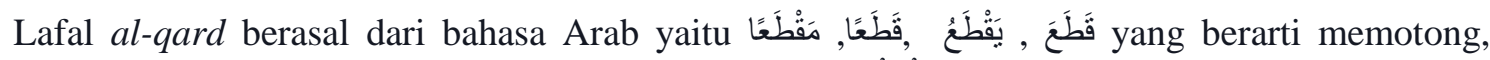
memutuskan sesuatu ${ }^{7}$ Al-qardhu secara bahasa artinya adalah آَلََْطْعُ (memotong). Dinamakan demikian karena pemberi utang (muqridh) memotong sebagian hartanya dan memberikannya kepada pengutang. ${ }^{8}$

Menurut terminologi al-qardh adalah memberikan harta kepada orang yang mengambil manfaatnya, lalu orang tersebut mengembalikan gantinya. ${ }^{9}$ Menurut Abdul Ghofur Anshori dalam bukunya Hukum Perjanjian Islam di Indonesia, beliau mengatakan bahwa al-qardh adalah meminjamkan sesuatu kepada orang lain dengan kewajiban mengembalikan pokoknya kepada pihak yang meminjamkan. ${ }^{10}$

Secara umum al-qardh atau utang piutang adalah penyerahan sejumlah uang, barang dan sejenisnya untuk dikembalikan pada saat tiba waktunya dengan nilai/jumlah yang sama.

Penyerahan berarti melepaskan sejumlah uang atau barang kepada orang lain untuk dipergunakan manfaatnya dalam kurung waktu tertentu. dan mengembalikan dengan jumlah dan nilai yang sama, berarti tidak ada penambahan nilai pada uang atau barang tersebut. Sehingga murni tujuannya untuk membantu tanpa ada maksud untuk mendapatkan keuntungan dan motif tertentu dari piutangnya.

Pemberian utang ini merupakan salah satu bentuk kasih sayang dan tolong menolong. Rasulullah menamakannya maniiha karena orang yang meminjamkan manfaatnya kemudian mengembalikan kepada pengutang. Memberikan utang adalah disunnahkan dan orang yang melakukannya mendapatkan pahala yang besar.

Firman Allah Swt. dalam Q.S. Al-baqarah/2: 245.

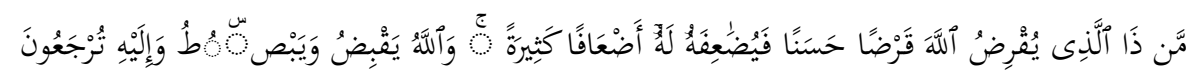

Terjemahnya:

Siapakah yang mau memberi pinjaman kepada Allah, pinjaman yang baik (menafkahkan hartanya di jalan Allah), Maka Allah akan meperlipat gandakan pembayaran kepadanya dengan lipat ganda yang banyak. dan Allah menyempitkan dan melapangkan (rezki) dan kepada-Nya-lah kamu dikembalikan. ${ }^{11}$

Hadits Rasulullah Saw dari Ibnu Majah :

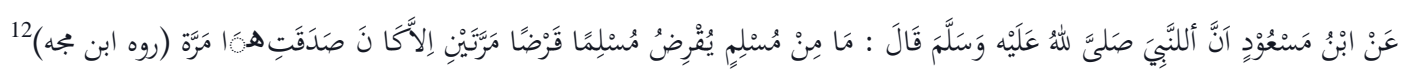

Artinya:

${ }_{8}^{7}$ Mahmud Yunus, Kamus Arab-Indonesi, h. 348;

${ }^{8}$ Mahmud Yunus, Kamus Arab-Indonesia, h. 337;

${ }^{9}$ Saleh Al- Fauzan, Fiqh Sehari-Hari, (Jakarta: Gema Insani, 2005), Cet. Ke-1, h. 410;

${ }^{10}$ Abdul Ghofur Anshori, Hukum Perjanjian Islam Di Indonesia, (Yogyakarta: Gajah Mada University Press,2010), h. 36;

${ }_{11}^{11}$ Mohamad Taufiq, Quran In Word: Q.S. Al-baqarah/2: 245;

${ }^{12}$ Muhammad Bin Yazid Qazzawaini, Shahih Ibnu Majah, (Lebanon: Darul Pakkir, Tth), h. 15; 
Dari Ibnu Mas'ud bahwa sesungguhnya Nabi Saw bersabda: tidak ada seorang muslim yang memberi pinjaman kepada muslim yang lain dua kali, melainkan nilainya sama seperti sedekah satu kali. (HR. Ibnu Majah).

Banyak dalil yang menyinggung tentang keutamaan saling membantu dan meringankan kesulitan orang lain. Dalil tersebut bersumber dari Al-quran dan Hadits, dan pada umumnya menyebutkan keutamaan terhadap orang yang menutupi kekurangan sesama muslim.

\section{METODE PENELITIAN}

Jenis penelitian ini adalah tinjauan hukum islam terhadap tindakan atau praktek arisan bangun rumah oleh warga untuk memenuhi kebutuhan tempat tinggalnya. Terhadap Penelitian ini menggunakan metode penelitian deskriptif. Metode penelitian merupakan cara ilmiah untuk mendapatkan data dengan tujuan dan kegunaan tertentu ${ }^{13}$ dengan mempertimbangkan jenis dan karakteristik obyek penelitian.

Istilah "deskriptif" berasal dari kata bahasa Inggris to describe yang berarti memaparkan atau menggambarkan sesuatu hal, misalnya keadaan, kondisi, situasi, peristiwa, kegiatan dan lain-lain. ${ }^{14}$ Dengan demikian, penelitian deskriptif adalah jenis penelitian yang dimaksudkan untuk menyelidiki keadaan, kondisi atau hal-hal lain yang kemudian hasilnya dipaparkan dalam bentuk laporan penelitian. Sementara kualitatif merupakan istilah dalam penyajian data dari sebuah penelitian yang diwujudkan dalam bentuk kata keadaan atau kata sifat. Misalnya, "sangat baik" disingkat SB, "baik" kemudian disingkat B sebagai gambaran kualitasnya.

Penulis menggunakan metode tour the quetions dalam melakukan penelitian ini dengan bentuk observasi, wawancara dan dokumentasi. Observasi dilaksanakan dengan cara memasuki lokasi penelitian dengan melakukan pengamatan secara sistematis dengan prosedur standar dan bertahap. Wawancara tahap selanjutnya adalah teknik wawancara dengan beberapa narasumber diantaranya, para pelaku yaitu anggota kelompok arisan bangun rumah, pengamat yaitu orang yang dianggap memiliki kapasitas dalam memberikan data informasi diantaranya toko masyarakat (aparat Desa) dan Toko Agama.

Instrumen atau alat penelitian yang digunakan untuk memudahkan peneliti utuk mengimpun dan mengolah data adalah penulis itu sendiri, dengan memanfaatkan kapasitas teori yang telah diperoleh selama bangku kuliah. Kemudian penulis menguji keabsahan dari berbagai data yang telah diperoleh tersebut dengan melakukan perpanjangan pengamatan, meningkatkan ketekunan, dan membercheck, dan menggunakan referensi.

\section{HASIL DAN PMBAHASAN}

\section{A. Praktek Arisan Bangun Rumah Tinggal dengan Sistem Arisan di Kampung Kamande}

Praktek bangun rumah tinggal dengan sistem arisan merupakan bagian dari praktek muamalah yang dilakukan masyarakat Kampung Kamande Desa Pollewani. Tujuan dari arisan ini yaitu untuk mempermudah ketersediaan rumah bagi warga Kampung Kamande. Diawal perkembangannya, arisan ini beranggotakan karib kerabat saja dengan obyek arisan yang berkisar pada material bangunan seperti semen, batu merah besi dan lain-lain. Namun, pada tahun 2017 arisan ini sudah terdiri dari 70 orang anggota yang terbagi lagi dalam 3 kelompok, masing-masing kelompok terdiri dari 20-25 orang anggota. Produk arisan pun sudah merembek kepada ketenaga-kerjaan dalam membangun rumah. Ketenaga kerjaan yang dimaksud adalah para buruh dan kepala bangunan terdiri dari anggota kelompok itu sendiri, sehingga dalam membangun rumah tidak harus mengeluarkan biaya khusus untuk arsitek dan kuli bangunan. Kelompok arisan ini juga sudah memiliki peralatan seperti sebuah mesin molen beton hercules.

\footnotetext{
${ }^{13}$ Dr.Sugiyono, Metode Penelitian Kuantitatif, Kualitatif dan R\&D, (Cet.XII; Bandung: Alfabeta 2011) h.
}

2

${ }^{14}$ Suharsimi Arikunto, Prosedur Penelitian: Suatu Pendekatan Praktek. (Ed. Rev. Cet.14; Jakarta: Rineka Cipta) h.3; 
Mesin ini diperoleh dari masing-masing anggota kelompok untuk membantu meringankan proses pembangunan rumah bagi seluruh anggota.

Kelompok arisan Kampung Kamande ini telah mendirikan 7 buah rumah dari tahun 2017 hingga tahun 2020. Jumlah rumah yang dibangun setiap tahun adalah 1-2 rumah, dimana setiap bangunan hanya akan memakan waktu 10 hari kerja. Jumlah rumah yang dikerjakan akan sangat bergantung kepada hasil pertanian warga, hal ini karena sumber mata pencaharian secara umum adalah petani, sehingga arisan hanya diundi pada waktu panen.

Arisan bangun rumah Kampung Kamande hanya terdiri dari ketua kelompok dan para anggota arisan, ketua kelompok dijalankan oleh Rusli dan 20 anggota kelompok diantaranya Mawardi, Masjud, Abdullah, Ha'damang dan Sageng. Ketua kelompok dan seluruh anggota diwajibkan menyetor uang minimal Rp.1,000,000, disetiap musim, kemudian bergotong royong dalam membangun rumah. Sikap kekerabatan antara anggota kelompok menjadi aset utama sehingga kepercayaan masih terjalin secara harmonis. Dengan demikian, kegiatan dari kelompok arisan ini dapat berjalan dengan baik. Kegiatan dari kelompok arisan ini adalah mengumpulkan uang dari setiap anggota dengan jumlah minimal Rp.1,000,000, material bangunan, dan ketenaga kerjaan. Kemudian dalam pertemuan sederhana dilakukan pengundian, dan nama anggota yang keluar menjadi sasaran pekerjaan rumah dengan modal pokok yang telah terkumpul dari setiap anggota. Rumah akan dikerjakan oleh seluruh anggota selama 10 hari kerja, kemudian selebihnya akan diselesaikan oleh pemilik rumah.

Kegiatan arisan bangun rumah Kampung Kamande ini memiliki prospek yang sangat baik, ditinjau dari segi sosial maupun ekonomi. Dari segi sosial, dengan adanya arisan bangun rumah ini dapat turut serta dalam melestarikan tradisi gotong royong, sehingga imbasnya tidak hanya dalam hal kegiatan kelompok namun juga meningkatkan kepedulian sosial antara warga. Dari segi ekonomi, dengan adanya arisan bangun rumah ini terbukti sangat membantu perekonomian warga dengan hemat biaya dalam membangun rumah juga memudahkan warga untuk memiliki tempat tinggal yang layak. Selain itu, dengan adanya arisan bangun rumah ini akan meminialisir timbulnya sifat iri hati antara warga tetangga sebab rumah yang dimiliki merupakan hasil dari gotong royong. Iri hati merupakan penyakit hati yang dicelah dalam islam karena awal mula dari segala penyakit adalah hati.

1) Visi dan Misi Kelompok Arisan Bangun Rumah Kampung Kamande a). Visi

Visi menurut KBBI adalah kemampuan untuk melihat pada inti sebuah persolan, wawasan apa yang tampak dalam khayal, penglihatan atau pengamatan. ${ }^{15}$ Jadi visi merupakan suatu cara pandang sebuah organisasi terhadap harapan yang ingin di capai di masa yang akan datang.

Visi yang dibangun kelompok arisan bangun rumah Kampung Kamande adalah menyediakan rumah yang layak huni demi menciptakan kesejahteraan keluarga bagi warga Kamande Desa Pollewani Kecamatan Tutar Kabupaten Polewali Mandar.

b). Misi

Menurut KBBI misi adalah tugas yang dirasakan orang sebagai suatu kewajiban untuk melakukannya. Jadi misi merupakan tugas khusus yang menjadi tanggung jawab seseorang atau sekelompok orang yang harus dilaksanakan guna merealisa sikan tercapainya visi. Adapun Misi kelompok arisan rumah Kampung Kamande yaitu sebagai berikut :

a. Merawat serta melestarikan tradisi gotong royong dalam pembangunan,

b. Menabung bersama untuk kesejahteraan bersama,

c. Menggali potensi desa untuk didaya gunakan,

2) Jenis dan Permodalan

a) Jenis-jenis Arisan

${ }^{15}$ Kamus Besar Bahasa Indonesia (KBBI) Versi Online. Kbbi.web.id 
Jenis-jenis arisan merupakan produk utama yang ditawarkan oleh kelompok arisan bangun rumah Kampung Kamande kepada warga yang telah bergabung sebagai anggota kelompok. Adapun jenisjenis arisan tersebut yaitu berupa uang, tenaga kerja, dan konsumsi.

Arisan ini menariknya karena terdiri dari beberapa macam, karena ada arisan uang, barang dan juga para pekerja bangunan itu dari seluruh anggota. Tidak ada pihak luar yang ikut dalam proses pengerjaan bangunan, tukang dan buru kita-kita ji sebagai anggota. ${ }^{16}$

b) Permodalan

Permodalan adalah jumlah atau nilai arisan yang harus disetor sesuai jenis arisan yang sudah menjadi kesepakatan bersama dari seluruh anggota, yaitu uang Rp.1,000,000,- 10 hari kerja, serta makanan dan konsumsi.

Setoran yang diwajibkan hanya uang saja sebesar Rp.1,000,000,- setiap periode, arisan yang lainnya itu tergantung masing-masing anggota, misalnya ia tidak mampu bekerja selama sepuluh hari tetap bisa ikut arisan uangnya, tapi untuk pembangunan rumahnya ia harus mencari tukang sendiri. ${ }^{17}$

\section{3). Manfaat Serta Peran}

Berdasarkan hasil observasi dan wawancara, penulis menyimpulkan bahwa ada beberapa peran penting yang cukup dirasakan manfaatnya oleh warga dengan adanya arisan bangun rumah tinggal ini yaitu sebagai berikut:

a) Sebagai Tabungan

Orang yang berpenghasilan tidak menentu akan cenderung punya sifat boros, Arisan menjadi solusi yang paling tepat untuk menabung. Pada umumnya warga Kamande hanya berprofesi sebagai petani yang memiliki target penghasilan yang tidak menentu karena bergantung kepada kondisi pertanian. Dengan mengikuti arisan, menabung merupakan hal yang wajib dilakukan karena anggota arisan mempunyai kewjiban untuk membayar setoran setiap periode. Dan akan mendapatkan pembayaran atas setoran tersebut pada suatu periode arisan.

Kita sebagai petani kan penghasilannya tidak menentu, bahkan kadang juga kita gagal panen, jadi kalau mau menabung orang seperti kita ini otomatis sulit, sementara membangun rumah tentu butuh dana besar. ${ }^{18}$

b). Sebagai Wadah Silaturrahmi

Selain sebagai wadah untuk menabung, kelompok arisan ini juga sebagai wadah untuk menjalin silaturrahmi.

Arisan ini juga menjadi tempat silaturrahmi antara warga, karena ada pertemuan-pertemuan rutin diadakan, sampai pada proses pembangunan yang berlangsung selama beberapa hari. Ini akan memberi kesan kebersamaan yang sangat luar biasa. ${ }^{19}$

Manfaat arisan ini, disamping kebutuhan finansial juga bisa sebagai wadah silaturrahmi. Menyambung silaturrahmi memeri manfaat yang amat besar, pertama memudahkan rejeki dan ke dua memanjangkan umur. Silaturrahmi yang terjalin dengan baik tentunya akan membantu masyarat untuk hidup rukun dan damai.

c) Sebagai Tempat Bersosialisasi

\footnotetext{
${ }^{16}$ Bpk. Rusli, ketua kelompok arisan. wawancara 20 Maret 2020;

${ }^{17}$ Bpk. Rusli, ketua kelompok arisan. wawancara 20 Maret 2020;

${ }^{18}$ Bpk. Sageng, salah satu anggota arisan Kampung Kamande, wawancara pada tanggal 20 Maret 2020;

${ }^{19}$ Bpk. Rusli Selaku kelompok arisan, wawancara 12 Maret 2020;
} 
Selain menjalin silaturrahmi, mengikuti arisan juga sebagai tempat atau cara bagi setiap peserta untuk bersosialisasi. Hal ini tentunya akan berimbas bukan hanya dalam urusan arisan melainkan solidaritas akan ikut terbangun terhadap unsur-unsur sosial lainnya.

Adanya arisan ini menjadi dorongan untuk bekerja sama secara gotong royong, bukan hanya pembangunan rumah melainkan urusan diluar dari pada itu. Contohnya kan selesai rumahmu dibangun dalam jangka waktu kurang dari sepuluh (10) hari ya dialihkan ke lokasi lagi. ${ }^{20}$

d) menjadi Peran untuk Kerukunan Warga

Arisan bangun rumah ini, selain perannya sebagai tempat silaturrahmi antara masyarakat juga dapat membangun kerukunan antara warga. Sebagai mana pernyataan salah satu toko masyarakat sebagai berikut:

Arisan ini apabila di cermati, sangat banyak paedahnya karena bukan hanya menjadi wadah silaturrahmi antara warga, tapi juga menghilangkan sifat-sifat sombong! Jadi memang banyak dampak positifnya. ${ }^{21}$

Arisan bangun rumah ini dapat berperan dalam membangun kerukunan antara warga dalam hidup bertetangga. Menghilangkan berbagai sifat-sifat hati yang tercelah, seperti sifat iri hati, sombong, riya' dan lain sebagainya. Sifat-sifat semacam itu amat di celah dalam Islam sebab dapat memecah belah hubungan antara sesama. Dengan arisan ini akan membantu membunuh sifat-sifat semacam itu karena timbul kesadaran bahwa rumah yang dimiliki meskipun lebih megah dari rumah tetangga, akan tetapi hasil dari kerja sama dan tidak lepas dari gotong royong antara warga.

e). Memudahkan dalam Membangun Rumah

Arisan bangun rumah ini telah mendirikan beberapa rumah dengan atap seng dan dinding dari batu merah bahkan sudah ada yang menggunakan lantai keramik. Dengan kondisi geografis dengan letak daerah pelosok, tentu akan sulit untuk akses pembangunan sehingga hal ini terbukti bahwa peran arisan bangun rumah Kampung Kamande Desa Pollewani sangat memudahkan warga.

Selama tiga tahun berjalan baru bisa mendirikan empat rumah, bangunan pertama itu tahun 2017, kemudian tahun 2018 ada dua rumah lagi yang dibangun dan terakhir pada awal 2019. Tahun ini banyak anggota yang belum bisa setor modal lagi karena gagal panen selalu hujan. Mudahmudahan akhir tahun ini pembayarannya bisa rampung agar bisa lancar pembangunan lagi ${ }^{22}$

4) Gambaran Umum Proses Arisan

\section{a) Setoran Arisan}

Arisan yang awalnya terdiri dari arisan material bangunan ini, telah menjadi arisan yang begitu komplit. Selain setoran uang dan tenaga, juga tidak lepas dari makanan dan konsumsinya. Uang setoran sebesar Rp.1,000,000,-/ musim, dan tenaga selama sepuluh (10) hari kerja ditambah makanan konsumsi. Arisan konsumsi ini melibatkan ibu-ibu rumah tangga dengan menyetor beras satu (1) Liter beras, dan uang Rp. 25,000,-/orang. Uang tersebut digunakan untuk membeli kelengkapan dapur seperti minyak, ikan sayur dan lain-lain.

Arisan ini kan ada tiga, uang tenaga dan konsumsi. Uang itu disetor Rp.1000,000,-/musim. Tenaganya nanti kalau sudah proses pembangunan. Jadi setiap hari akan diabsen kalau ada yang berhalangan dan tidak bisa hadir, maka nanti setelah selesai 10 hari kerja baru dia masuk untuk membantu yang punya rumah dalam proses-proses selanjutnya. Sementara arisan konsumsi itu ibu-

\footnotetext{
${ }^{20}$ Bpk. Masjud, anggota kelompok arisan, wawancara 12 Maret 2020;

${ }^{21}$ Bpk. Andi Nasrullah, S.Pd., sebagai Kapala Desa Pollewani, wawancara 12 Maret 2020;

${ }^{22}$ Wawancara, Bpk Rusli, selaku ketua kelompok arisan Kampung Kamande. Tanggal 12 Maret 2020;
} 
ibu yang urus dengan mengumpulkan beras 3 Liter ditambah uang 50.000 untuk keperluan memasak, karena selama sepuluh hari kerja itu kan kita makan ${ }^{23}$

b). Pengundian

Pengundian dilakukan dengan cara mengocok kertas yang berisi nama setiap anggota menggunakan kaleng botol, sehingga nama yang keluar pertama menjadi penerima undian membangun rumah. Proses pengundian ini wajib dihadiri oleh seluruh anggota, di rumah salah satu anggota yang telah disepakati.

Pengundian biasanya dilaksanakan setiap kali setelah rampung pembangunan. Ini modalnya kan sebagai modal utama saja kekurangannya akan ditambah oleh pemilik rumah. kadang juga ada yang menolak jika mendapat undian. ${ }^{24}$

Proses pengundian dilakukan setiap awal arisan atau selepas pembangunan rumah, sehingga penerima undian akan mengetahui lebih awal dan mempersiapkan segala sesuatu untuk pembangunan rumahnya di musim berikutnya. Mereka yang belum siap akan menolak atau mengalihkan undiannya tersebut kepada yang lebih membutuhkan atau dengan cara melakukan pengocokan ulang.

Proses pengundian ini sifatnya terbuka dan akan disaksikan oleh seluruh peserta arisan. Adapun anggota arisan yang berhalangan untuk hadir akan menyetujui seluruh ketentuan pengundian yang dilakukan.

c) Penyetoran dan Penagihan

Besaran setoran yang diwajibkan kepada seluruh anggota kelompok arisan ini adalah dari jenis uang Rp.1,000,000,- dan tenaga selama 10 hari kerja. Uang tersebut di setor kepada ketua kelompok, dengan sekali bayar atau dengan cara cicilan selama periode musim. Sementara tenaga kerja akan terhitung selama proses pembangunan dengan menggunakan absensi. Adapun anggota yang tidak rutin hadir selama 10 hari, maka akan ber-hutang kepada penerima undian dan akan melunasinya setelah hari kerja.

Tenaganya nanti kalau sudah proses pembangunan. Jadi setiap hari akan diabsen kalau ada yang berhalangan dan tidak bisa hadir, maka nanti setelah selesai 10 hari kerja baru dia masuk untuk membantu yang punya rumah dalam proses-proses selanjutnya. ${ }^{25}$

Arisan ini sama hal-nya dengan arisan secara umum yaitu mengumpulkan sejumlah uang atau barang. Sehingga terkadang ada anggota yang tidak mampu membayar setoran tersebut dalam periode tertentu. Hal tersebut akan menghambat proses pembangunan karena tentu pengundian akan tertunda selama satu musim. Peran ketua kelompok adalah mengontrol pembayaran seluruh anggota dan melaukan penagihan jika diperlukan.

Peserta arisan ini rata-rata keluarga ji semua, kita juga sama-sama punya rasa tidak enakan jadi saling mengerti saja mi antara anggota. Saya juga meskipun sebagai ketua kelompok tapi kalau kondisinya anggota benar-benar tidak ada yah harus ditunda pembangunan dulu, seperti periode ini kan musim hujan sehingga banyak yang gagal panen jadi kita tunda pembangunan. Adapun kalau tersisa satu atau dua orang saja yang belum membayar, hanya diberi tahu saja mereka juga

\footnotetext{
${ }^{23}$ Wawancara dengan bpk.Rusli selaku ketua arisan Kampung Kamande pada tanggal 20 Maret 2020;

${ }^{24}$ Wawancara dengan bpk.Rusli selaku ketua arisan Kampung Kamande pada tanggal 20 Maret 2020;

${ }^{25}{ }^{25}$ Wawancara dengan bpk.Rusli selaku ketua arisan Kampung Kamande pada tanggal 20 Maret 2020;
} 
sudah mengerti dan berusaha untuk membayar. Jari intinna inde' jama-jamangang gotong royong untuk mempermudah urusan jadi saling mengerti anggota. ${ }^{26}$

Proses penagihan biasanya dilakukan oleh ketua kelompok maksimal tiga kali, seluruh anggota akan mengerti dan langsung menyetor, meskipun dengan cara menyicil. Tenggang rasa dan juga beban moral setiap anggota menjadi modal utama eksisnya kelompok arisan Kampung Kamande. Hal ini dapat dipengaruhi karena mereka masih saling mengenal betul antara satu dengan yang lainnya. "Keluargakeluarga semua ji satu rumpung, tidak ada istilah na-sibiring karena sudah saling kenal. Apa lagi satu kampung jadi gampang komunikasinya, 27

d) Pembangunan

Proses terakhir dari praktik arisan Kampung kamande ini adalah proses pembangunan. Proses ini, kehadiran seluruh anggota akan di absen setiap hari oleh ketua kelompok. Pembangunan dilaksanakan selama sepuluh (10) hari dengan perincian sebagai berikut :

Pagi : pukul $07.00 \mathrm{~s} / \mathrm{d} 12.00$ (sarapan 40 menit)

Sore : pukul $14.00 \mathrm{~s} / \mathrm{d} 17.00$ (break 40 menit)

Proses pembangunan selama sepuluh hari kerja terkadang tidak mampu merampung-kan seluruh pengerjaan bangunan, sesuai ukuran besar rumah masing-masing yang ditentukan oleh pemilik rumah. Sehingga proses selanjutnya akan dilanjutkan oleh pemilik rumah dibantu anggota arisan yang tidak full absensi hariannya.

Gampang karena yang tidak masuk kerja akan mengisi kekosongan absensinya setelah selesai 10 hari. Rumah yang dikerja kan ukurannya berbeda-beda, sesuai desain rumah yang diinginkan pemiliknya. Jadi kalau rumahnya besar tentu tidak akan rampung semua selama 10 hari. Nah disitulah kesempatannya kalau ada anggota yang tidak full absennya untuk mengganti hariannya yang masih kosong. Kalau-pun ada yang tidak cukup sepuluh hari bangunannya sudah selesai tinggal dialihkan ke lokasi (coklat) ma'bela (babat rumput). ${ }^{28}$

Modal yang terkumpul dari setiap anggota, sebagai modal awal yang tidak mutlak bisa menutupi seluruh biaya selama proses pembangunan. Hal itu tergantung ukuran rumah yang diinginkan oleh pemilik, sehingga modal selebih-nya akan menjadi tanggungan pribadi pemilik rumah.

\footnotetext{
${ }^{26}$ Wawancara dengan bpk.Rusli selaku ketua arisan Kampung Kamande pada tanggal 9 Juni 2020;

${ }^{27}$ Waeancara, Bpk Masjud, salah satu peserta arisan Kampung Kamande. Tanggal 9 Juni 2020;

${ }^{28}$ Waeancara, Bpk Masjud, salah satu peserta arisan Kampung Kamande. Tanggal 9 Juni 2020;
} 
Tabel 4.3. Daftar jumlah iuran pokok dan jenis arisan Kampung Kamande.

\begin{tabular}{|c|c|c|c|c|}
\hline No & Iuran Pokok & $\begin{array}{c}\text { Waktu Kerja (8 } \\
\text { jam/hari diluar } \\
\text { jam istirahat) }\end{array}$ & $\begin{array}{c}\text { Konsumsi } \\
\text { (sarapan \& } \\
\text { makan siang) }\end{array}$ & Nilai Akhir \\
\hline 1 & Rp.1,000,000,- & 10 hari & $(\sqrt{ })$ & Rp.20,000,000,- X 10 X Jaminan \\
\hline 2 & Rp. $1,000,000,-$ & 10 hari & $(\sqrt{ })$ & Rp.20,000,000,- X 10 X Jaminan \\
\hline 3 & Rp.1,000,000,- & 10 hari & $(\sqrt{ })$ & Rp.20,000,000,- X 10 X Jaminan \\
\hline 4 & Rp.1,000,000,- & 10 hari & $(\sqrt{ })$ & Rp.20,000,000,- X 10 X Jaminan \\
\hline 5 & Rp. $1,000,000,-$ & 10 hari & $(\sqrt{ })$ & Rp.20,000,000,- X 10 X Jaminan \\
\hline 6 & Rp.1,000,000,- & 10 hari & $(\sqrt{ })$ & Rp.20,000,000,- X 10 X Jaminan \\
\hline 7 & Rp.1,000,000,- & 10 hari & $(\sqrt{ })$ & Rp.20,000,000,- X 10 X Jaminan \\
\hline 8 & Rp.1,000,000,- & 10 hari & $(\sqrt{ })$ & Rp.20,000,000,- X 10 X Jaminan \\
\hline 9 & Rp. $1,000,000,-$ & 10 hari & $(\sqrt{ })$ & Rp.20,000,000,- X 10 X Jaminan \\
\hline 10 & Rp.1,000,000,- & 10 hari & $(\sqrt{ })$ & Rp.20,000,000,- X 10 X Jaminan \\
\hline 11 & Rp. $1,000,000,-$ & 10 hari & $(\sqrt{ })$ & Rp.20,000,000,- X 10 X Jaminan \\
\hline 12 & Rp.1,000,000,- & 10 hari & $(\sqrt{ })$ & Rp.20,000,000,- X 10 X Jaminan \\
\hline 13 & Rp.1,000,000,- & 10 hari & $(\sqrt{ })$ & Rp.20,000,000,- X 10 X Jaminan \\
\hline 14 & Rp.1,000,000,- & 10 hari & $(\sqrt{ })$ & Rp.20,000,000,- X 10 X Jaminan \\
\hline 15 & Rp.1,000,000,- & 10 hari & $(\sqrt{)}$ & Rp.20,000,000,- X 10 X Jaminan \\
\hline 16 & Rp.1,000,000,- & 10 hari & $(\sqrt{)}$ & Rp.20,000,000,- X 10 X Jaminan \\
\hline 17 & Rp. $1,000,000,-$ & 10 hari & $(\sqrt{ })$ & Rp.20,000,000,- X 10 X Jaminan \\
\hline 18 & Rp.1,000,000,- & 10 hari & $(\sqrt{ })$ & Rp.20,000,000,- X 10 X Jaminan \\
\hline 19 & Rp.1,000,000,- & 10 hari & $(\sqrt{ })$ & Rp.20,000,000,- X 10 X Jaminan \\
\hline 20 & Rp.1,000,000,- & Sageng & - & Rp.20,000,000,- \\
\hline
\end{tabular}

\section{B. Tinjauan Hukum Islam Terhadap Praktek Bangun Rumah Tinggal dengan Sistem Arisan di Kampung Kamande}

Arisan bangun rumah yang dilakukan masyarakat Kampung Kamande tidak jauh berbeda dengan arisan-arisan pada umumnya. Arisan adalah sekelompok orang yang melakukan pembayaran iuran berupa uang atau barang dan jasa, kemudian uang atau barang tersebut akan diberikan dengan cara mengundi. Undian dilakukan dalam satu pertemuan yang wajib dihadiri oleh seluruh anggota, nama yang keluar dalam undian akan berutang, sementara anggota yang belum mendapat undian akan berpiutang kepada yang telah mendapat undian lebih awal. Hal itu terus dilakukan secara berulang hingga seluruh anggota mendapatkan undian dan tidak ada lagi utang dan piutang diantara anggota peserta.

Obyek arisan yang dilakukan masyarakat Kampung Kamande adalah berupa uang, barang dan jasa. Iuran yang diwajibkan kepada setiap anggota sebesar Rp.1,000,000,- untuk berupa barang yaitu material bangunan dan makanan konsumsi, sementara yang berupa jasa yaitu tenaga dari seluruh anggota selama sepuluh (10) hari untuk mengerjakan rumah.

Transaksi arisan di Kampung Kamande cenderung kepada utang-piutang, jika dilihat dari segi rukun dan syarat utang-piutang :

a. 'Aqaid (pihak yang berakad)

Pihak-pihak yang berakad yaitu muqridh (orang yang berpiutang) dan muqtaridh (orang yang berhutang. Setelah melalui proses pengundian arisan maka dapat diketahui siapa yang berhtang dan yang berpiutang yaitu : 
1) Setiap anggota yang namanya keluar lebih awal dalam pengundian arisan adalah sebagai orang yang berhutang karena ia harus membayar angsuran setiap pengundian arisan, dan angsuran tersebut harus dilakukan sampai seluruh anggota mendapat undian masing-masing.

2) Setiap anggota yang namanya keluar lebih akhir adalah orang yang berpiutang karena setiap pengundian ia telah membayar uang setoran kepada ketua arisan dan setoran tersebut diberikan kepada orang yang mendapat undian lebih awal. Sehingga secara tidak langsung ia telah memberikan piutang kepada orang yang telah mendapat undian lebih awal.

\section{b. Shigat (ijab dan qabul)}

Ijab adalah lafal yang dikeluarkan oleh pihak yang berpiutang yang mengandung makna penyerahan hak miliknya untuk dipiutangkan. Qabul adalah lafal yang mengandung makna kesediaan menerima piutang yang akan dikembalikan pada waktu yang telah ditentukan.

Arisan bangun rumah Kampung Kamande dalam pelaksanaannya adalah setiap peserta arisan melakukan pengumpulan sejumlah uang atau barang kepada ketua kelompok untuk diundi dan dipiutangkan kepada yang mendapat undian, setelah proses pengundian maka kalimat ijab akan diwakilkan kepada ketua kelompok dan qabul dari anggota yang mendapat undian.

c. Ma'qud Alaih (benda yang dihutangkan)

Benda yang dihutangkan yaitu sesuatu yang bernilai dan tidak dalam kepemilikan orang lain. Benda yang dihutangkan dalam transaksi arisan Kampung Kamande adalah berupa uang, barang dan tenaga dari seluruh anggota yang menjadi obyek arisan.

Sementara syarat-syarat utang-piutang yaitu :

a. Aqa'id hendaknya Ahliyah atau kecakapan untuk melakukan tabarru',

b. Ma'qud Alaih tidak dalam kepemilikan orang lain.

Praktek arisan bangun rumah Kampung Kamande Desa Pollewani Kecamatan Tutar berdasarkan paparan diatas yaitu syarat (Ahliah dan Ma'qud Alaih tidak dalam kepemilikan orang lain) serta rukun utang-piutang (akad, ijab qabul dan ma'qud alaih) sehingga arisan ini cenderung menggunakan akad utang-piutang (al-qardh).

Arisan bangun rumah Kampung Kamande dari hasil penelitian penulis tidak menemukan penyimpangan dan eksploitasi antara anggota melainkan perkumpulan warga yang berinisiatif saling membantu dan bersosialisasi untuk memudahkan satu urusan dan pekerjaan "Kalau ini arisan betul-betul untuk kemaslahatan yang hampir tidak ada mudharatnya"29. Ini senada dengan perintah Allah Swt. Dalam Q.S. Al-Maidah/5: 2.

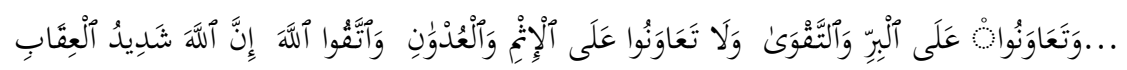

Terjemahnya:

...dan tolong-menolonglah kamu dalam (mengerjakan) kebajikan dan takwa, dan jangan tolongmenolong dalam berbuat dosa dan pelanggaran. dan bertakwalah kamu kepada Allah, Sesungguhnya Allah amat berat siksa-Nya. ${ }^{30}$

Berdasarkan uraian sebelumnya, praktek arisan bangun umah di Kampung Kamande merupakan kategori utang piutang. Syariat Islam mengakui legalitas dari akad utang piutang atau dikenal dengan istilah Al-qardh. Sebagai mana bunyi hadits Rasulullah Saw sebagai berikut.

Selanjutnya ditegaskan dalam Hadits Rasulullah Saw dari Ibnu Majah :

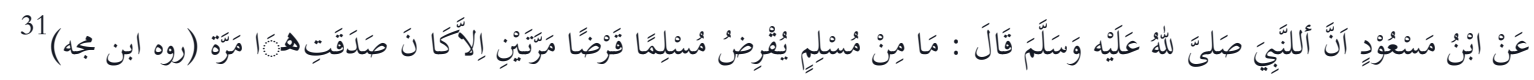

\footnotetext{
${ }^{29}$ Abdul Hamid, S.Pd.I.,M.A, sebagai praktisi agama Desa Pollewani, wawancara 10 Juni 2020;
}

${ }^{30}$ Mohamad Taufiq, Quran In Word: Q.S. Al-ma'idah/5: 2; 
Artinya:

Dari Ibnu Mas'ud bahwa sesungguhnya Nabi Saw bersabda: tidak ada seorang muslim yang memberi pinjaman kepada muslim yang lain dua kali, melainkan nilainya sama seperti sedekah satu kali. (HR. Ibnu Majah).

Berdasarkan paparan di atas, penulis menyimpulkan bahwa praktik bangun rumah tinggal dengan sistem arisan di Kampung Kamande, termasuk kategori muamalah dan hukumnya adalah mubah (boleh).

\section{KESIMPULAN}

Berdasarkan hasil penelitian tentang "Praktek Bangun Rumah Tinggal dengan Sistem Arisan dalam Tinjauan Hukum Islam" di Kampug Kamande Desa Pollewani Kecamatan Tutar Kabupaten Polewali Mandar, maka penulis menyimpulkan sebagai berikut:

A. Arisan bangun rumah tinggal di Kampung Kamande sama seperti arisan yang ada pada umumnya, yakni adanya sekelompok orang dimana setiap anggota di wajibkan untuk menyetor sejumlah uang dengan besaran nilai nominal Rp.1000,000,-/musim. Uang dan barang (material bangunan) yang terkumpul tersebut kemudian diberikan kepada yang mendapatkan undian. Undian dilaksanakan dengan cara melakukan pertemuan sederhana di sebuah tempat yang telah ditentukan, pertemuan ini wajib dihadiri oleh seluruh anggota. Hal ini dilakukan secara berulang sampai seluruh anggota mendapatkan undian. Tujuan kelompok arisan ini adalah mendirikan rumah bagi setiap anggota dengan lebih mengutamakan kerja sama dan gotong royong.

B. Praktek arisan bangun rumah di Kampung Kamande berdasarkan penelitian penulis adalah menggunakan akad Al-qardh (utang piutang). Utang piutang merupakan akad yang legalitasnya dibolehkan dalam Islam karena termasuk kategori muamalah. Oleh karena itu, hukum dari praktek bangun rumah tinggal dengan sistem arisan di Kampung Kamande adalah mubah (boleh), dengan pertimbangan bahwa seluruh proses yang dijalankan oleh kelompok arisan ini tidak terdapat hal-hal yang menyimpang dari nilai-nilai syariat Islam.

\section{DAFTAR PUSTAKA}

Alqur-an, Terjemahan. Kementrian Agama RI.

Al-Syaukani. 2006. Ringkasan Nailul Authar/ Syaikh Faishal Bin Abdul Azis Al Mubarak; Penerjemah, Amir Hamzah Fachrudin, dan Asep Saefullah. Jakarta: Pustaka Azzam. Cet. Pertama.

Anshori, Abdul Ghofur. 2010. Hukum Perjanjian Islam di Indonesia. Yogyakarta: Gajah Mada University Press.

Arikonto Suharsimi. 2010. Prosedur Penelitian Suatu Pendekatan Praktik. Edisi Revisi, Cet. XIV. Jakarta: Rineka Cipta.

Azzam, Muhammad Abdul Azis. 2010. Fiqih Muamalat Sistem Transaksi dalam Fiqih Islam. Jakarta: Amzah.

Fauzan, al- Saleh. 2005. Figh Sehari-hari. Jakarta: Gema Insani. Cet. Pertama.

Ghazali, Abd. al-Rahman. 2010. Fiqh Muamalah. Jakarta: Kencana.

Hamid, Abdul, Wawancara. Kamande Desa Pollewani.10 Juni 2020.

Http://sc.syekhnurjati.ac.id, Landasan Teori Fiqih Muamalah. pdf .

Kbbi.web.id. Kamus Besar Bahasa Indonesia (KBBI).

Maryuni, Y. 2015. Tinjauan Teoritis Arisan. Repository.uin-suska.ac.id. pdf.

${ }^{31}$ Muhammad Bin Yazid Qazzawaini, Shahih Ibnu Majah, (Lebanon: Darul Pakkir, Tth), h. 15; 
Masjud. Wawancara. Kamande Desa Pollewani. 9 Juni 2020.

Muslich, Ahmad Wardi. 2010. Fiqh Muamalat. Jakarta: Amzah, Cet. Pertama.

Nasrullah, Andi. Wawancara. Kamande Desa Pollewani. 25 Maret 2020.

Poerwadarminta, W.J.S. 2003. Kamus Umum Bahasa Indonesia, Jakarta: Balai Pustaka.

Pujileksono Sugeng. 2015. Metode Penelitian Komunikasi Kualitatif. Malang: Intrans Publishing.

Ridwan, M.B.A. 2009. Metode \& Teknik Menyusun Proposal Penelitian. Cet. Pertama, Bandung: ALFBETA.

Rifa'i, Moh. 1978. Fiqh Islam Lengkap. Semarang: PT. Karya Toha Putra.

Ritonga, Rahman A. 2006 Ensiklopedi Hukum Islam. Jakarta: PT. Ichtiar Baru Van Hoeve. 6 Jil. Cet. Pertama.

RPJMDes (Rencana Pembangunan Jangka Menengah Desa), Desa Pollewani. 2019-2024. h.21-26;

Rusli. Wawancara. Kamande Desa Pollewani. 20 Maret 2020.

Sageng. Wawancara. Kampung Kamande, 20 Maret 2020

Sitompul, Mhd. Syahman. Jurnal.uincu.ic.id. Implementasi surah Al-baqarah:282 dalam Pertanggung Jawaban Masjid di Sumatera Timur. Fakultas Ekonomi dan Bisnis Islam Universitas Islam Negeri Sumatera Utara.

Sugiyono. 2011. Metode Penelitian Kuantitatif Kualitatif dan R\&D. Bandung: ALFABETA, Cet 12.

Taufiq, Mohamad. Quran in Word. Ver. 1.0.0.

Umar, Muh. Zakaria. 2017. Pembangunan Rumah Tinggal dengan Sistim Arisan di Desa Pangan Jaya. Jurusan Arsitektur, Universitas Halu Oleo, Indonesia: EMARA Indonesian Journal of Architecture.Vol. 3 Nomor 1

Unasman, Fakultas Agama Islam. 2018. Pedoman Penulisan Karya Tulis Ilmiah Makalah, Skripsi, dan Laporan Penelitian. pdf.

Qazzawaini, Yazid, bin Muhammad. Shahih Ibnu Majah, (Lebanon: Darul Pakkir, Tth), h. 15;

Yunus Mahmud. 1989. Kamus Arab Indonesia. Jakarta: PT. Hida Karya Agung. 